\title{
The changing face of employment relations: equality and diversity
}

\author{
Sian Moore and Stephanie Tailby \\ Faculty of Business and Law, University of the West of England, Bristol, UK
}

\begin{abstract}
Purpose - The purpose of this paper is to explore what has happened to the notion and reality of equal pay over the past 50 years, a period in which women have become the majority of trade union members in the UK. It does so in the context of record employment levels based upon women's increased labour market participation albeit reflecting their continued over-representation in parttime employment, locating the narrowed but persistent overall gender pay gap in the broader picture of pay inequality in the UK.
\end{abstract}

Design/methodology/approach - The paper considers voluntary and legal responses to inequality and the move away from voluntary solutions in the changed environment for unions. Following others it discusses the potential for collective bargaining to be harnessed to equality in work, a potential only partially realised by unions in a period in which their capacity to sustain collective bargaining was weakened. It looks at the introduction of a statutory route to collective bargaining in 2000 , the National Minimum Wage from 1999 and at the Equality Act 2010 as legislative solutions to inequality and in terms of radical and liberal models of equality.

Findings - The paper suggests that fuller employment based upon women's increased labour market activity have not delivered an upward pressure on wages and has underpinned rather than closed pay gaps and social divisions. Legal measures have been limited in the extent to which they have secured equal pay and wider social equality, whilst state support for collective solutions to equality has waned. Its replacement by a statutory minimum wage initially closed pay gaps, but appears to have run out of steam as employers accommodate minimum hourly rates through the reorganisation of working time.

Social implications - The paper suggests that statutory minima or even voluntary campaigns to lift hourly wage rates may cut across and even supersede wider existing collective bargaining agreements and as such they can reinforce the attack on collective bargaining structures, supporting arguments that this can reduce representation over pay, but also over a range of other issues at work (Ewing and Hendy, 2013), including equality.

Originality/value - There are then limitations on a liberal model which is confined to promoting equality at an organisational level in a public sector subject to wider market forces. The fragmentation of bargaining and representation that has resulted will continue if the proposed dismantling of public services goes ahead and its impact upon equality is already suggested in the widening of the gender pay gap in the public sector in 2015.

Keywords Gender, Labour market, Government policy, Equality, Collective bargaining, Trade union recognition

Paper type Conceptual paper

The 50th anniversary of the Manchester Industrial Relations Society coincides with a period in which women have become the majority of trade union members in the UK (Department for Business, Innovation and Skills (BIS), 2014); an "insurgence" which may have been unimaginable at the society's 
inception. The MIRS half-centenary, nonetheless, is proximate in time to that of the fight for gender equality in pay and grading sparked by women sewing machinists at Ford's Dagenham site which, without achieving the women's demand for skilled status (which took a further strike, 16 years on), was a catalyst for the 1970 Equal Pay Act. The obvious issue is what has happened since to the notion and reality of equal pay and particularly in the context of record employment levels (Office for National Statistics (ONS), 2015) based upon women's increased labour market participation albeit reflecting their continued over-representation in part-time employment?

The opening section of this paper delineates trends. In summary, women's labour market participation has increased, although not as yet to equal men's (there has not as yet been a revolution in the gendered division of unpaid care work); the overall gender pay gap has narrowed but remains substantive and above the OECD average notwithstanding a relatively high rate of women's employment in the UK; women predominate among the low paid whose ranks have increased markedly since the 1980s. More broadly, in the context of the market solutions which governments have embraced since the "profits squeeze" of the 1970s, the wage share of national income has been squeezed in most rich countries but in the UK in particular the squeeze has been borne by middle- and low-paid workers; earnings growth has been concentrated at the top of the earnings range (Lansley and Reed, 2013).

Subsequent sections of the paper consider voluntary and legal responses as "vehicles for equality" (Briskin, 2006, p. 12), the tensions and potential complementarities between them and the move away from voluntary solutions in the changed environment for unions since the 1960s and 1970s. Discussed is the potential for collective bargaining to be harnessed to the objectives of equality and diversity in work and employment, a potential only partially realised by unions in a period in which their capacity to sustain collective bargaining was weakened (Colling and Dickens, 2001). As part of subsequent union demands for legal solutions, a statutory route to collective bargaining was introduced from 2000 but is littered with hurdles, provides for recognition for a limited range of bargaining issues and can be part of the dynamic of bargaining unit fragmentation; examples concern workforces transferred from the public to the private sector. Similarly, the National Minimum Wage (NMW) from 1999 has provided a floor to low pay but one which is porous in the context of the reconfiguration of working time and extended use of zero-hours contracts, underemployment and "self-employment" and this argument can be extended to the voluntary living wage. The Equality Act is discussed in terms of its legislative solution to inequality, but there is also consideration of the concurrent emergence of Trade Union Equality Representatives, albeit without statutory support. Here the discussion is attentive to the shifting relationship between radical and liberal models of equality, and also the intersections of gender, race, ethnicity and class. Finally the paper considers how far such social divisions have been reinforced such that a "precariat" defined in terms of gender, age, race and ethnicity has established itself as a function of a "dual labour market" which trade unions have failed to challenge.

\section{Participation and pay gaps}

Britain's employment rate of 73 per cent in the first-quarter of 2015 was the highest since comparable records began in 1971. Alongside an increase in student part-time work, the upward trend reflects a decline in the male rate from 92 per cent in 1971 to 78 per cent and an increase in the female rate from 53 per cent in 1971 to 69 per cent (ONS, 2015). Reforms over the past two decades have aimed to encourage women's labour market participation and to "make work pay" (Working Families Tax Credit), although some groups will lose with the introduction of Universal Credit from 2017 (Azmat, 2015). From 2008 there was requirement for single parents to work, and the increase in the state 
pension age in 2010 will mean fewer women aged between 60 and 65 years retiring (ONS, 2013). At the same time there are different estimates of women's and men's contribution to unemployment in the recession following the 2007/2008 financial crash, according to the time span selected, but the Fawcett Society (2013) reckoned that women accounted for 100 per cent of the increase from the beginning of 2010 to the autumn of 2012.

Fuller labour market participation has not resulted in equal pay. In 2014 the overall gender pay gap was 19.1 per cent (based on median gross hourly earnings) which is higher than the OECD average of 15 per cent (cited in Azmat, 2015). The full-time gender pay gap was 9.4 per cent. Yet it is part-time employment that constrains equality; women working part-time (over two-fifths of the female employment total) on average earn $\mathrm{f5.15}$ per hour less than full-time men, a gender pay gap of 38 per cent. Worryingly the 2014 figures also saw an increase in the gender pay gap in the public sector, from 9.5 to 11 per cent, whilst that in the private sector decreased from 19.2 per cent to 17.5 per cent. This gap, in a sector which has introduced equal pay regimes, may be driven by privatisation and the impact of budget cuts on women in the public sector (Fawcett Society, 2014).

The gender pay gap is part of the wider picture of pay inequality. The growth in executive pay means that whilst in 1979 the top 10 per cent took home 28 per cent of national income; by 2007 this had grown to 40 per cent (High Pay Commission, 2012). At the same time evidence suggests convergence at the bottom; in 2013 the gender pay gap was highest at the top end and had not closed as much as for those in the lowest earning groups (DCMS, 2014). The Resolution Foundation reported that 26 per cent of women workers were low paid compared to 16 per cent of men, but the proportion of low-paid men had increased (Whittaker and Hurrell, 2013). Similarly it has been shown that the ethnic pay gap largely disappears for women employed part-time (Metcalf, 2009) suggesting intersections of class, race and gender.

Crucially labour's share of GDP has fallen: it averaged 59 per cent in the 1950s and 1960s, peaked at 66 per cent in 1975 and by 2007 had declined to 53 per cent (Lansley and Reed 2013). The retreat from the Fordist model involved the contraction of the scope and coverage of national, sectoral and enterprise bargaining in liberal market economies over three decades, albeit an uneven process within and between EU countries. The figures are now familiar. Collective bargaining covered 71 per cent of the workforce in late 1970s, whilst Wages Councils set minimum pay rates for a further 11 per cent. By 201229 per cent of the workforce were covered, predominantly in the public sector; the figures for the private sector were just 16 per cent (van Wanrooy et al., 2013). At the same time the proportion of workers falling below the low-pay threshold (two-thirds of gross hourly median pay among all employees) rose from a low of 15 per cent in 1975 to a peak of 23 per cent in 1996 and the proportion changed modestly in the 2000s (Whittaker and Hurrell, 2013, p. 1).

Historically, at least in the private sector, collective bargaining has been seen as exclusive and sectional (e.g. Virdee, 2000). Blackett and Sheppard $(2002,2003)$ in their analysis for the International Labour Organisation showed that access to collective bargaining was unequal in OECD countries in the twentieth century, when rates of collective bargaining coverage were otherwise high. Labour law could omit from the right to bargain collectively workers whose work (or workplace) deviated from the "industrial model"; Fordism's "fictions" (the male breadwinner, society is homogeneous) could result in de facto exclusions. Disproportionately represented among the excluded were historically disadvantaged societal groups, discriminated against in the labour market on the basis of gender, race, ethnicity, country of origin, ability, age and/or religion. 


\section{Equity bargaining}

In the later decades of the twentieth century the potential for harnessing (Dickens, 2000) or bending (Heery, 2006) collective bargaining to the promotion of equality at work was tested. For Dickens (2000, pp. 205-206) "harnessing collective bargaining as a mechanism for the promotion of gender equality implies radical change in the traditional platforms and approaches of much collective bargaining and poses challenges to the existing nature of many trade unions". The promotion of equality bargaining - turning the resource of collective bargaining to the objectives of equality and diversity in work and employment - was a result of the reform of the internal structures of unions, including the formal selforganisation of black, women, disabled and gay and lesbian workers, a radical model of equality based upon the recognition of difference. Pressure for internal gender equality in UK unions began to build from the mid-1970s with a pivotal role played by feminist women trade union activists, agitating for positive action. In 1979 the TUC published its Charter for Equality for Women within Trade Unions, which encouraged unions to establish separate women's committees and ensure women's representation in decision making bodies: although whilst giving women agency such measures do not automatically transform male culture (Kirton and Greene, 2002; Kirton, 2014). The TUC adopted a Black Workers Charter in 1981 and in 1984 recognised black workers' self-organisation rights, albeit initially largely confined to the public sector union UNISON.

Dickens (2000, pp. 196-197) identified five respects in which collective bargaining can be advantageous for gender equality over legal regulation: flexibility, acceptability, legitimacy, enforcement and voice. Initiatives may be more acceptable and effective if they are tailored and targeted to local circumstances. Co-determination may lessen resistance to equality measures. Collective bargaining structures and mechanisms provide ready-made policing and enforcement mechanisms, whilst because they are representative (in contrast to top-down legislative intervention), they allow women a voice, "an ability to define their own needs and concerns and to set their own priorities for action". Blackett and Sheppard (2003) similarly conclude that collective bargaining "whose rationale is deeply rooted in notions of social justice, egalitarianism, democratic participation and freedom" - has potential to promote equality (p. 421). Briskin (2006, pp. 12-13) distinguishes between "equity bargaining" and "bargaining equity". The former "refers to the process of bargaining, bargaining strategy and includes issues such as the gender of negotiators". Bargaining equity refers to "the issues on an equity agenda". Briskin uses the term equity on the principle that equality can be imbued with the liberal conceptualisation of equal treatment. In respect to gender equality Dickens (2000, pp. 205-206) has similarly argued that it is insufficient to add on women to existing bargaining agendas or as members of unions that remain unchanged. Yet as a result of qualified and uneven union transformation around the Millennium, social relationships became legitimate issues for inclusion in collective agreements (Danieli, 2006) - family-friendly policies such as maternity or paternity leave or maternity support leave or pay, parental leave, adoption leave, compassionate or bereavement leave and time-off for domestic emergencies.

From early in the twenty-first century women became the majority of union members; in 2002 the proportion of female employees who were in a trade union was around 28 per cent, compared with 23 per cent for male employees. In 2013 women represented 55 per cent of aggregate union membership although it has to be stressed that the total has halved since the end of the 1970s. Black British workers are more likely to be union members than "all employees" ( 29 compared to 26 per cent in 2013) and this is particularly true for black women. Female Black British workers are most likely to be union members (BIS, 2014). This trend is in part accounted for the concentration of black and 
female workers in the public sector, but also has to be set against the overall decline in union membership and union power. In the UK women's increased participation in the labour market occurred within a period where a combination of industrial transformation and political volition was undermining the basis of collective bargaining. The paradox observed by Colling and Dickens (2001, p. 14) was that unions "discovered" the need to act effectively on behalf of women (and other social groups they had underrepresented) when "their ability to do so was particularly constrained". Further, as Marchington et al. (2004) have described, the constraints on collective solutions are particularly felt in the context of organisational fragmentation within the economy and its impact on representation and joint regulation.

\section{Transforming bargaining units}

The 2010-2015 Conservative-Liberal Democrat Coalition government's determination to reduce the size of the state intensified the role of the private sector in public service delivery (Tailby, 2012). Exposure to competitive pressures erodes terms and conditions, a tendency that is reinforced by the fragmentation of workforces and their removal from collective bargaining coverage, existing representation structures and union organisation. The prevalence of female and black workers in the public sector (Runnymede, 2011) means privatisation and outsourcing raise key equality issues. This concentration of women, black and migrant workers in privatised services implies intensified divisions of labour on the basis of gender and, in some geographical areas, by race and ethnicity (Wills et al., 2010). The removal of workers away from direct employment in local government, health or higher education, detaches them from the union's immediate influence. Although the delivery of privatised services is concentrated in the hands of a small group of multi-national companies, workers are employed on a multiplicity of small contracts characterised by divergent working conditions and fragmented representation and bargaining. Since union branches have traditionally been organised on a single employer basis, directly employed branch officers have been denied facility time to represent or organise workers employed by contractors or to negotiate over their employment. A survey of UNISON branches as part of research undertaken as part of UNISON's migrant worker participation project revealed that overall just over a third (36 per cent) of branch secretaries reported that their branch did not recruit amongst private contractors providing services to their employer (Moore and Watson, 2009).

\section{Legal solutions?}

In the context of the decline of collective bargaining and union membership UK unions pressed for legal intervention. The Labour Government responded by implementing a statutory trade union recognition procedure from 2000 . This enables unions that can demonstrate majority support within a specified bargaining unit to be recognised for collective bargaining in the workplace. However, unlike previous recognition procedures the Labour Government did not intend that the law should promote collective bargaining. It is a last resort in circumstances where employers and unions cannot reach a voluntary agreement over recognition. Following an award of statutory recognition the employer is only obliged to bargain on pay, hours and holidays. The Labour Government stated that equality and training were important aspects of the employment relationship, but did not add them to the core bargaining issues contained in the statutory model of bargaining that may be imposed if the parties are unable to come to their own agreement following the recognition award (Department for Trade and Industry, 2000). 
Analysis of statutory recognition agreements emerging from the procedure found that over three quarters were confined to negotiating over pay, hours and holidays (McKay et al., 2005) and that following the introduction of the statutory procedure the limitations of the statutory model of collective bargaining had begun to extend to voluntary collective agreements concluded in its shadow (Moore et al., 2004). In the sample of voluntary agreements, equal opportunities were specified as a subject of bargaining in less than one in ten ( 8 per cent) and specifically excluded in one-third (31 per cent). Fewer than one in ten ( 7 per cent) agreements provided for collective bargaining on familyfriendly policies (maternity or paternity leave or maternity support leave or pay, parental leave, adoption leave, compassionate or bereavement leave and time-off for domestic emergencies). In terms of the content of recognition agreements equal opportunities appeared to be a procedural issue, although family-friendly policies offered the opportunity for more substantive gains in terms and conditions. Limited statutory support for collective bargaining in the workplace did not promote equality.

Privatisation and outsourcing processes have become manifest in the statutory recognition procedure, where increasingly recognition claims are based upon small bargaining units covering workers on contracts outsourced to private sector organisations and resulting in contract-based bargaining units covering very small numbers of workers. This reflects the wider fragmentation of employment relations and resultant employer and union strategies within the procedure which have introduced tensions between organisational and representative imperatives (Moore et al., 2013). These tensions arise because unions are forced to adopt tactics that define bargaining units in their own immediate interests; in supporting contract-based recognition unions are reinforcing the dissolution of collective bargaining and collective organisation that privatisation and outsourcing are designed to facilitate at a national and organisational level.

The privatisation of public services has meant that the earlier sectoral concentration of recognition claims has shifted, with public service unions moving slowly into the arena of statutory recognition. The Central Arbitration Committee's (CAC), (the body that administers the UK statutory recognition procedure) 2011/2012 Annual Report commented on the 10 per cent decline in the proportion of applications from manufacturing, transport and communication over the previous year, one area where public sector restructuring is reflected in CAC statistics is social care, where local authorities have transferred directly employed, mainly female staff, to private care homes. Public service unions have been forced to resort to the statutory recognition process to safeguard representation for members removed from the protection of national collective bargaining agreements afforded by direct employment in the public sector. The continual cycle of commissioning means these bargaining units have a potentially transitory existence, so that the Transfer of Undertakings Regulations (TUPE) has played an increasing role in statutory recognition and its application to outsourced services has been "clarified" (see Pownall, 2013). Moore et al. (2013) confirm the minimal impact of the statutory recognition procedure in extending union recognition for collective bargaining and argue that the law has encouraged a limited form of joint regulation that promotes rather than overcomes a historic divide between industrial and equality issues. The wider and longer term evidence is the continued contraction of collective bargaining coverage associated with wage inequality (Brown et al., 2001).

\section{Equality duties}

In tandem with union attempts to reinvigorate collective bargaining through statutory means was their push for new equality legislation. Hepple (2010) describes the Equality Act 2010 as "part of the 
fifth generation of equality legislation in Britain" (p. 11) unifying half a century of anti-discrimination legislation that began with the Race Relations Act in 1965. The legislation addresses discrimination on six strands: sex, racial and ethnic origin, disability, age, religion and sexual orientation. The original Bill also, for the first time, included the legal concept of multiple discrimination, but the secondary legislation was not enacted by the incoming Conservative-Liberal Democratic Coalition. The public sector equality duties, a duty on public authorities to promote equality and address discrimination in the exercise of public functions, have, however, been seen as an important adjunct to individual rightsbased legislation for addressing discrimination (Squires, 2008, 2009; Fredman, 2011). Conley (2012) particularly notes the use that trade unions could make of the equality duties. Conley and Page (2010) have highlighted the importance of the specific duty to produce equality impact assessments in achieving the objectives of the equality duties. However, once again the privatisation of public services removes swathes of workers from the remit of the requirements on public sector bodies, including the equal pay comparators that large public sector organisations provided.

Under the Labour Government the Equality Bill provided the context for the introduction of workplace trade union Equality Reps (ERs). For the TUC, ERs are uniquely placed to promote fairness in the workplace. They can do this first, by raising the equality agenda among fellow workers and in their own unions; second, by encouraging employers to make equality and diversity part of mainstream collective bargaining; and third by working with "vulnerable workers" and trying to ensure that every worker receives fair treatment irrespective of gender, race, disability, religion, age, gender reassignment or sexuality (TUC, 2009). The Labour Government rejected the TUC's argument for statutory rights to paid time-off, facilities and training, but did provide $f 1.5$ million through the Union Modernisation Fund for pilot projects "to help develop a union infrastructure to support the workplace activities of equality representatives, for example through training and development" (Government Equalities Office and Schneider-Ross Ltd, 2009). The TUC (2012) Equality Audit found that over a quarter (28 per cent) of unions had provision in their rulebook or practice for the nomination or appointment of ERs in the workplace.

For Squires the Equality Bill was consistent with the liberal model of equality, based upon sameness or equal treatment. In their study of ERs in two public sector unions (Public and Commercial Services union (PCS), and UNISON). Moore and Wright (2010) found that ERs were often reluctant to positively identify in terms of race, gender, class, sexuality, disability or age, but were concerned with a more abstract concept of "fairness" between individuals rather than social groups. This implied a more formally inclusive approach to equality than the single-strand focus of self-organisation. ER views may reflect the prevailing legislative and policy trends and chime with the wider move from equality to managing diversity that has become the mantra of human resource management at the organisational level (Kandola and Fullerton, 1998). There is a tension then between the equal treatment or sameness conceptions driving the ER role and the radical or difference perspective underpinning self-organisation. Yet the evaluations of the UNISON and PCS ER projects (Kandola and Fullerton, 1998) suggested that there is complementarity and the potential for a close relationship, rather than conflict, between ERs and the self-organised networks and the possibility for ERs to reinvigorate self-organisation. ERs may play a transformative role that mainstreams equality concerns by seeking to change both union and workplace cultures. Booth and Bennett (2002) characterise this as a "gender perspective" (as distinct from a "difference approach"), because it focuses on gender (rather thanthe underrepresented group, "women") and acknowledges the relevance of men's experience to the equality debate and to achieving change. In PCS a project officer described how the ER project had been effective in mainstreaming equality concerns across the union and how this was 
transcending a previous separation between industrial and equality issues. Transcendence was not anticipated by Daniels and Mcllroy (2009), who, in discussing the roles of both ERs and Union Learning Representatives (ULRs), proposed that "the restricted nature of the roles they offer cannot be minimised or downplayed" (p. 140) because the functions of the ER do not involve collective bargaining and joint regulation. Similarly the introduction of ULRs (also often seen as a gendered function) and ERs, for Ewing (2005), shift the role of unions away from the regulation of employment relations through collective bargaining and towards individual representation, with unions seduced by the Labour Government's provision of public funding to support the role. Whilst the reality of the workplace suggests a more contradictory outcome, the emergence of ERs may reflect a model of equality based upon the individualised rather than collective assertion of rights.

\section{The minimum and living wage and hours}

The establishment of a NMW, campaigned for by unions in the face of growing pay dispersion, marks a further move away from the voluntarist approach enshrined in collective bargaining. Its introduction by the Labour Government in 1999 through the establishment of the Low Pay Commission explicitly aimed to improve pay at the bottom of the wage structure (Grimshaw and Rubery, 2010, p. 354). In terms of impact around a third of low-paid employees were on extreme low pay in 1997 (hourly wages below one-third of gross median hourly pay for all employees) and the proportion was two per cent in 2012 (Whittaker and Hurrell, 2013). The Low Pay Commission (2013) Report showed the median gender pay gap had declined over the previous year from 9.6 to 8.6 per cent stating "this continues a trend that began at the same time as the introduction of the minimum wage". It reports that the gender pay gap has nearly halved over this period from 15.9 per cent in 1998 to 8.6 per cent in 2012. However, the "ripple effect" of the NMW has been smaller than was anticipated and, in the wake of lobbying from the Confederation of British Industry, from 2006 settlements reflected realignment with average earnings growth. Grimshaw et al. (2014) record examples of bottom-weighted pay settlements, as part of union pay equity campaigns to raise the base rate premium over the minimum. It would seem, however, that in the absence of unions and collective bargaining the NMW in many instances has been used as "the going rate". A growing spike at the wage floor has replaced the long tail of extreme low pay and the share of low-wage employment has remained high (Grimshaw et al., 2014; Whittaker and Hurrell, 2013).

The limitations of statutory intervention have provoked a reassertion of voluntarism through community-based campaigns for a living wage. The challenges that the decline in collective bargaining and fragmentation of work has posed for unionisation have led to mobilisations beyond the workplace often initiated by so-called "hard to organise" workers, including migrants (Stewart et al., 2009). The living wage campaign calculates an hourly rate, which ensures a minimum acceptable standard of living and which is above the NMW. Yet Pennycock (2012) calculated that only 10,000 workers had won a living wage between 2005 and 2011, while an estimated 5.24 million people in the UK were earning below the living wage in 2013: 21 per cent of all employees (ONS ASHE). The proportion of women earning below the living wage was 27 per cent compared to 17 per cent for men, largely because part-time jobs are far more likely to pay below the living wage than full-time. The rise in living costs has led to an increase in jobs paying below living wage (Markit Group, 2013).

Whilst the NMW and the living wage may lift hourly rates at the bottom, there is some evidence that employers can accommodate the rates through the reconfiguration of hours. In the service sector introduction of a NMW or living wage has been accompanied by the removal of weekend and evening premia, or by cuts in weekly or annual hours (Lopes and Hall, 2015) so that workers may not achieve 
any real increase in weekly, monthly or annual earnings. Bessa et al. (2013) explored low pay in the homecare sector and found that between 2008 and 2012 median hourly rates were 15 per cent above the NMW. However, the widespread practice of employing homecare workers on zero-hours contracts meant they were not guaranteed work and thus a stable weekly wage. Unpaid labour time due to the non-payment of travel time between home visits and episodic working time (unpaid waiting time between visits) meant that staff were not (once hourly rates were averaged out over time available to the employer) in reality receiving a NMW.

Government figures record an increase of 33 per cent in zero-hours contracts between 2011 and 2012, although public awareness of such contracts may confuse recording. However an ONS survey in 2014 found that nearly half of big companies use a total of 1.4 million zero-hours contracts. Hayes and Moore's (2014) study of homecare workers confirmed that zero-hours contracts are a key mechanism through which "unproductive" time is managed out of the labour process with paid and unpaid working time blurred since care workers are required to be constantly available to their employers and/or having to wait around in periods between visits. Zero-hours contracts thus facilitate the unpaid labour of women workers. They effectively restructure working time, by introducing episodic working where workers, are not paid for time between shifts despite being available to the employer. The TUC (2014) suggests they are associated with lower hourly rates; they found that the average hourly wage for a worker on a zero-hours contract was $£ 8.83$ an hour - a third less than the average for staff on permanent contracts ( $€ 13.39)$.

This focus upon working time is borne out by Blanchflower and Bell's index of underemployment (the numbers who want more hours in their existing jobs); by their calculations in the final quarter of 2014 the seasonally adjusted rate of underemployment in the UK was 7 per cent, well above the unemployment rate of 5.7 per cent (The Independent, 29 April 2015). A TUC report based upon the Labour Force survey stated that at 3.4 million the current level of underemployment is over a million higher (46 per cent) than it was before the recession; whilst unemployment has fallen by over 400,000 since early 2012, underemployment has risen by 93,000 . Blanchflower reports that women are much more likely to be underemployed than men, with the gap between the female underemployment and unemployment rates more than two percentage points compared to 0.9 for men. Underemployment is also high amongst those under the age of 25; 3.4 times the equivalent rate for all workers. The Bell and Blanchflower index has also suggested that ethnic minorities, in particular Black or Black British workers have high rates of underemployment (National Institute Economic Review, 2 May 2013). The underemployed and those on zero-hours contracts are not necessarily experiencing insecurity defined by job tenure (which can be disguised by TUPE transfers), but in terms of the security of hours and income.

In Germany, the introduction of a NMW has been seen as emblematic of a dual labour market, where management and labour coalitions secure collective agreements at plant level providing job security in return for flexibility, at the expense of a peripheral workforce, comprising temporary, agency and low-level - or marginal - part-time workers whose low pay is subsidised by the state (Hassel, 2014) and who are removed from legal employment protections. In the UK the peripheral may be mirrored by the expansion of zero hours, minimal or flexible contracts, self-employment and underemployment as outlined above. However, this apparently increased, gendered and racialised segmentation between core and peripheral workers has been challenged, including by Crouch (2015, p. 29), on the basis that the two forms of employment "exist alongside and in tension with each other" and the emergence of groups of "outsiders" is a result of this interaction. Such divisions have been blurred by economic crisis and budget cuts which have undermined the perceived security of public 
sector jobs. In this context the outsourcing of homecare has transformed a previously permanent, unionised stable female workforce, with a workplace, into isolated, unrepresented labour dependent upon zero-hours contracts. In this sense segmentation is not an outcome of female labour market participation (Adams and Deakin, 2014) but an attack upon it and upon the recognition of care as paid work and also what Adams and Deakin (2014) have described as the de-gendering of the standard employment relationship that took place at least to some extent in the twentieth century (p. 785).

Characterisations of a secure core suggest union complicity in the creation of "a precariat" and deny agency and the struggles of workers against attacks not only on their own pay and conditions, but also against the introduction of a new tier of workers on new and degraded contracts. The British Airways dispute of 2009-2011 is one example of where women and gay workers played a central part in a bitter conflict to prevent the introduction of a new mixed fleet on inferior terms and conditions (Taylor and Moore, 2015). Another example is that of women cleaners at Hillingdon Hospital who took action over reductions to their pay following the outsourcing of the service and their transfer to private contractor Pall Mall in 1995. A debate over dual labour markets has prevailed over 30 years and Pollert's (1988) initial critique remains pertinent: she warned against an ahistorical analysis and any model that asserts that segmentation is a departure from a previously homogeneous internal market and emphasised sectoral restructuring and change alongside generalised attacks on working conditions characterised by work intensification and rationalisation. Pollert suggests that employment security cannot be boiled down in practice to a reduction in the threat of job loss and also notes that dual labour market theory often excludes agency and the role of labour. Conley's (2008) review of Fevre's critique of the extent of job insecurity in the form of temporary work advocates the need for sectoral and occupational disaggregation and in particular attention to gender segregation. These arguments tend towards a more historically contingent account of the way divisions of labour by gender, age, race and ethnicity are renegotiated in periods of economic and industrial restructuring.

\section{Conclusions}

The past 50 years have seen a rise in levels of employment, in particularly amongst women, which has not delivered an upward pressure on wages and have underpinned rather than closed pay gaps and social divisions. Whilst a multi-pronged strategy, including both legal regulation and collective bargaining has been seen as affording the greatest potential for equality (Briskin, 2006; Dickens, 2000) a range of legal measures have been limited in the extent to which they have secured equal pay and wider social equality, whilst state support for collective solutions to equality has waned. Its replacement by a statutory minimum wage initially closed pay gaps, but appears to have run out of steam as employers accommodate minimum hourly rates through the reorganisation of working time. Statutory minima or even voluntary campaigns to lift hourly wage rates may cut across and even supersede wider existing collective bargaining agreements and as such they can reinforce the attack on collective bargaining structures. Ewing and Hendy (2013, p. 56) argue that a requirement for employers to pay a living wage, as in the case of the NMW, would reduce the capacity of workers to be represented at work over pay, and would have "no impact on the multitude of other issues that arise at work, including other terms and conditions". This must include equality and transcend separated industrial and equality agendas. Ewing and Hendy advocate the reinstatement of sector level collective bargaining in the interests of social justice and sustainable economic growth. The challenge is for a renewed system that is expansive and inclusive.

Equality entered the collective bargaining arena at the point when it was in decline, a decline associated with income disparity. Whilst arguments for the existence of a precariat abandoned by 
trade unions persist, for Adams and Deakin (2014) it is the neoliberal policy agenda that segments the workforce by subsidising low pay, suppressing real wages and reducing the influence of collective bargaining over pay (p. 798); it is this non-standard, marginal and underemployment that supports expanded employment figures. There are then limitations on a liberal model which is confined to promoting equality at an organisational level in a public sector subject to wider market forces (Moore and Wright, 2010). Further, in the context of the withdrawal of the state from welfare provision (Taylor-Gooby and Stoker, 2011) and subsequent developments in the commissioning of homecare. Hayes and Moore (2014) point out that the politics of austerity hinges upon gendered assumptions about the capacity of families to provide care, welfare and support on the basis of kinship; as well as on the harnessing of women's unpaid labour within a domestic or community context.

Ewing and Hendy (2013) point out that the UK now has the lowest level of collective bargaining coverage in Europe with the exception of Lithuania. Nonetheless there remains evidence of its importance for equality. Women are more likely to be covered by collective bargaining (Emery, 2012) - they predominate in health and education public services - and benefit more than men from the squeezed, but persistent, union pay premium (Bryson and Forth, 2010; BIS, 2014). The proposed further dismantling of public services will, however, severely challenge this and its impact is already suggested in the widening of the gender pay gap in the public sector.

\section{References}

Adams, Z. and Deakin, S. (2014), "Institutional solutions to precariousness and inequality in labour markets”, British Journal of Industrial Relations, Vol. 52 No. 4, pp. 779-809.

Azmat, G. (2015), "Gender gaps in the UK labour market: jobs, pay and family friendly policies", Election Economics Paper No. EA027, Centre for Economic Performance, The London School of Economics and Political Science, London.

Bessa, I., Forde, C., Moore, S. and Stuart, M. (2013), The National Minimum Wage, Earnings And Hours In The Domiciliary Care Sector, Low Pay Commission, London.

Blackett, A. and Sheppard, C. (2002), "The links between collective bargaining and equality", Working Paper No. 10, International Labour Office, Geneva, September.

Blackett, A. and Sheppard, C. (2003), "Collective bargaining and equality: making connections", International Labour Review, Vol. 142 No. 4, pp. 419-457.

Booth, C. and Bennett, C. (2002), "Gender mainstreaming in the European Union: towards the new conception and practice of equal opportunities?", European Journal of Women's Studies,

Vol. 9 No. 4, pp. 430-460.

Briskin, L. (2006), "Equality bargaining/bargaining equity. Restructuring eork and labour in the new economy (initiatives in the new economy)", Working Papers Series No. 2006-01, York University, Toronto.

Brown, W., Marginson, P. and Walsh, J. (2001), "The management of pay as the influence of collective bargaining diminishes", Working Paper No. 213, ESRC Centre for Business

Research, University of Cambridge, Cambridge.

Bryson, A. and Forth, J. (2010), “Trade union membership and influence 1999-2009”, Discussion Paper No. 362, NIESR, London, September.

Colling, T and Dickens, L. (2001), "Gender equality and trade unions: a new basis for mobilization?", in Noon, M. and Ojbonna, E. (Eds), Equality, Diversity and Disadvantage in Employment, Palgrave, Basingstoke, pp. 136-155.

Conley, H. (2008), "The nightmare of temporary work: a comment on fevre", Work, Employment and Society, Vol. 22 No. 4, pp. 731-736. 
Conley, H. (2012), "Using equality to challenge austerity: new actors and old problems", Work, Employment and Society Vol. 26 No. 2, pp. 349-359.

Conley, H. and Page, M. (2010), "The gender equality duty in local government: the prospects for integration", Industrial Law Journal, Vol. 39 No. 3, pp. 321-325.

Crouch, C. (2015), "Labour market governance and the creation of outsiders", British Journal of Industrial Relations, Vol. 53 No. 1, pp. 27-48.

Danieli, A. (2006), "Gender: the missing link in industrial relations research", Industrial Relations Journal, Vol. 37 No. 4, pp. 329-343.

Daniels, G. and McIlroy, J. (Eds) (2009), Trade Unions in a Neoliberal World: British Trade Unions under New Labour, Routledge Research in Employment Relations, Abingdon, Oxon.

Department for Business, Innovation and Skills (BIS) (2014), "Trade union membership 2013", Statistical Bulletin, Stationery Office, London.

Department for Culture Media and Sport (2014), "Secondary analysis of the gender pay gap: changes in the gender pay gap over time", Department for Culture Media \& Sport, London, March.

Department for Trade and Industry (2000), Trade Union Recognition (Method of Collective Bargaining) Order, TSO, London.

Dickens, L. (2000), "Collective bargaining and the promotion of gender equality at work: opportunities and challenges for trade unions", Transfer: European Review of Labour and Research Vol. 6 No. 2, pp. 193-208.

Emery, L. (2012), "Collectively agreed wages in the UK", Background paper European policy conference "Collectively agreed wages in Europe: challenges in the statistical and political field”, Brussels, 29 November.

Ewing, K. (2005), “The Function of Trade Unions”, Industrial Law Journal, Vol. 34 No. 1, pp. 1-22. Ewing, K.D. and Hendy, J. (2013), Reconstruction After the Crisis: A Manifesto for Collective Bargaining, The Institute for Employment Rights, London.

Fawcett Society (2013), The Changing Labour Market: Delivering for Women, Delivering for Growth, Fawcett Society, London.

Fawcett Society (2014), The Time to Act is Now, Fawcett's Gender Pay Gap Briefing, Fawcett Society, London.

Fredman, S. (2011), “The public sector equality duty”, Industrial Law Journal, Vol. 40 No. 4, pp. 405427.

Government Equalities Office and Schneider-Ross Ltd. (2009), "The Equality Bill. Creating a fair society", Fact Sheet, JN: 291946, Crown Copyright.

Grimshaw, D. and Rubery, J. (2010), "Pay and working time: shifting contours of the employment relationship", in Colling, T. and Terry, M. (Eds), Industrial Relations, Theory and Practice,

Wiley, London, pp. 349-377.

Grimshaw, D., Bosch, G. and Rubery, J. (2014), "Minimum wages and collective bargaining: what types of pay bargaining can foster positive pay equity outcomes?", British Journal of Industrial Relations, Vol. 52 No. 3, pp. 470-498.

Hassel, A. (2014), "The paradox of liberalization - understanding dualism and the recovery of the german political economy”, British Journal of Industrial Relations, Vol. 5 No. 1, pp. 57-81.

Hayes, L. and Moore, S. (2014), "Contracting for employability in domiciliary care: zero-hours, electronic monitoring and care plans as labour process 'technology' ", paper presented at 32nd International Labour Process Conference, King's College London, 7-9 April.

Heery, E. (2006), "Equality bargaining: where, who, why?", Gender, Work and Organization, Vol. 13 No. 6, pp. 522-542. 
Hepple, B. (2010), “The new single Equality Act in Britain”, The Equal Rights Review, Vol. 5, pp. 11-22.

High Pay Commission (2012), "Cheques with balances: why tackling high pay is in the national interest", Final Report of the High Pay Commission, High Pay Commission, London, December. Kandola, R. and Fullerton, J. (1998), The Diversity Mosaic' in Diversity in Action: Managing The Mosaic, 2nd ed., Institute of Personnel and Development, London.

Kirton, G. (2014), "Progress towards gender democracy in UK Unions 1987-2012", British Journal of Industrial Relations, Vol. 53 No. 3, pp. 484-507.

Kirton, G. and Greene, A. (2002), "The dynamics of positive action in UK trade unions: the case of women and black members", Industrial Relations Journal, Vol. 33 No. 2, pp. 157-173.

Lansley, S. and Reed, H. (2013), How to Boost the Wage Share, Touchstone Pamphlet 13, TUC Congress House, London.

Lopes, A. and Hall, T. (2015), "Winning a living wage: the legacy of the living wage campaign at UEL”, in Craig, G., Lewis, H., Skrivankova, K. and Waite, L. (Eds), Vulnerability,

Exploitation and Migrants: Insecure Work In A Globalised Economy, Palgrave, Basingstoke.

Low Pay Commission (2013), "National minimum wage: low pay commission report 2013",

Cm 8565, Her Majesty's Stationery Office, London.

McKay, S. and Moore, S. with Acas Research and Evaluation Section (2005), "The role of acas in trade union recognition claims under the employment relations act 1999", Acas Research

Paper, 03/05, London.

Marchington, M., Grimshaw, D., Rubery, J. and Willmott, H. (2004), Fragmenting Work: Blurring Organizational Boundaries and Disordering Hierarchies, Oxford University Press, Oxford.

Markit Group Limited (2013), "Living wage research for KPMG: structural analysis of hourly wages and current trends in household finances", Henley on Thames, Oxon.

Metcalf, H. (2009), "Pay gaps across the equality strands: a review", National Institute of Economic and Social Research, Research Report No. 14, Equality and Human Rights

Commission Research Report Series, Manchester.

Moore, S. and Watson, M. (2009), "UNISON migrant workers participation project", Evaluation Report, UNISON, London.

Moore, S. and Wright, T. (2010), "PCS equality representatives", Final Evaluation Report, Training, Development and Support Programme, Working Lives Research Institute, London.

Moore, S., McKay, S. and Bewley, H. (2004), "The content of new voluntary trade union recognition agreements 1998-2002: Volume One - an analysis of new agreements and case studies”, DTI Employment Relations Research Series No. 26, DTI, London.

Moore, S., McKay, S. and Veale, S. (2013), Statutory Regulation And Employment Relations:

The Impact of Statutory Recognition, Palgrave Macmillan, Basingstoke.

Office for National Statistics (ONS) (2013), "Full report - Women in the labour market",

25 September, Crown copyright.

Office for National Statistics (ONS) (2015), “UK Labour Market, March 2015”, Statistical Bulletin, 18 March.

Pennycock, M. (2012), What Price a Living Wage? Understanding the Impact of A Living Wage on Firm-Level Wage Bills, IRRP \& Resolution Foundation, London.

Pollert, A. (1988), "The flexible firm: fixation or fact", Work, Employment and Society, Vol. 2 No. 3, pp. 281-316.

Pownall, H. (2013), "Neoliberalism, austerity and the health and social care act 2012: the coalition government's programme for the NHS and its implications for the public sector workforce", Industrial Law Journal, Vol. 42 No. 4, pp. 422-433. 
Runneymede Trust (2011), "Ethnicity \& public sector employment during the current recession: a summary", from paper commissioned by Runneymede, by Prof Yaojun Li, University of Manchester.

Squires, J. (2008), "Intersectional inequalities: reflecting on the subjects and objects of inequality", The Political Quarterly, Vol. 79 No. 1, pp. 53-61.

Squires, J. (2009), "Intersecting Inequalities", International Feminist Journal of Politics, Vol. 11 No. 4, pp. 496-512.

Stewart, P.,McBride, J., Greenwood, I., Stirling, J., Holgate, J.,Tattersall, A., Stephenson, C. andWray, D.

(2009), “Understanding community unionism”, inMcBride, J. andGreenwood, I. (Eds), Comunity Unionism: A Comparative analysis of Concepts and Contexts, Chapter 1, Palgrave Macmillan, Basingstoke.

Tailby, S. (2012), "Public service restructuring in the UK: the case of the english national health service", Industrial Relations Journal, Vol. 43 No. 5, pp. 448-464.

Tailby, S. and Moore, S. (2014), "Collective bargaining; building solidarities through the fight against inequalities and discrimination", Cuadernos de Relaciones Laborales, Vol. 32 No. 2, pp. 361-384.

Taylor, P. and Moore, S. (2015), "Cabin crew collectivism: labour process and the roots of mobilisation in the british airways dispute 2009-11", Work, Employment and Society,

Vol. 29 No. 1, pp. 79-98.

Taylor-Gooby, P. and Stoker, G. (2011), "The coalition programme: a new vision for Britain or politics as usual?", The Political Quarterly, Vol. 82 No. 1, pp. 4-15.

TUC (2009), "TUC Equality Reps Project Report", TUC, London.

TUC (2012), "TUC Equality Audit 2012 Report”, TUC, London.

TUC (2014), Casualisation and Low Pay, TUC, London.

Virdee, S. (2000), "A Marxist critique of black radical theories of trade-union racism", Sociology,

Vol. 34 No. 3, pp. 545-565.

van Wanrooy, B., Bewley, H., Bryson, A., Forth, J., Freeth, S., Stokes, L. and Wood, S. (2013),

Employment Relations in the Shadow of Recession, Palgrave Macmillan, Basingstoke.

Whittaker, M. and Hurrell, A. (2013), Low Pay Britain 2013, Resolution Foundation, London.

Wills, J., Datta, K., Evans, Y., Herbert, J., May, J. and McIlwaine, C. (2010), Global Cities at Work:

New Migrant Division of Labour, Pluto Press, London.

\section{Further reading}

Briskin, L. (2014), “Austerity, union policy and gender equality bargaining”, Transfer: European Review of Labour and Research, Vol. 20 No. 1, pp. 115-133.

Colling, T. (2010), “Transformational governance, market making, and employment rights: current developments in Britain's Public Services Industry”, Employee Representation in the New World of Work: The Dynamics of Rights, Voice, Performance and Power, University of Laval, Quebec, 16-18 June.

Colling, T. and Dickens, L. (1989), Equality Bargaining: Why Not?, HMSO, London.

Ewing, K. (2005), "The function of trade unions", Industrial Law Journal, Vol. 34 No. 1, pp. 1-22.

Grimshaw, D and Rubery, J. (1998), "Integrating the internal and external labour markets",

Cambridge Journal of Economics, Vol. 22 No. 2, pp. 199-220.

Low Pay Commission (2012), "National minimum wage: Low Pay Commission Report 2012", Cm 8302, Her Majesty's Stationery Office, London.

Moore, S. and Wright, T. (2012), "Shifting models of equality? Union equality reps in the public services”, Industrial Relations Journal, Vol. 43 No. 5, pp. 433-447. 
Moore, S., Wright, T. and Conley, H. (2012), "Addressing discrimination in the workplace on multiple grounds - the experience of trade union equality reps", Acas Research Paper

No. 02/12, Acas, London.

Office for National Statistics (2014), “Annual survey of hours and earnings, 2014 provisional results", Statistical Bulletin.

Standing, G. (2011), The Precariat: The New Dangerous Class, Bloomsbury, London.

TUC (2010), "TUC Equality Reps Project Extension Report”, TUC, London.

Williamson, S. and Baird, M. (2014), "Gender equality bargaining: developing theory and practice”, Journal of Industrial Relations, Vol. 56 No. 2, pp. 155-169.

\section{About the authors}

Sian Moore is a Professor of Work and Employment Relations in Bristol Business School at the University of the West of England. She was previously a Principal Research Fellow in CERIC, University of Leeds, and prior to that a Reader at the Working Lives Research Institute at London Metropolitan University. She worked on the Leverhulme Future of Unions Programme at the London School of Economics and spent five years at the Labour Research Department. She is on the Editorial Board of Work, Employment and Society. Professor Sian Moore is the corresponding author and can be contacted at: Sian2.Moore@uwr.ac.uk

Stephanie Tailby is a Professor of Employment Relations in Bristol Business School at the University of the West of England and a Co-Director of the Centre for Employment Studies Research (CESR). She was President of the British Universities Industrial Relations Association (BUIRA) between 2004 and 2007 and a member of the Steering Committee organising the International Industrial Relations Association (IIRA) Congress convened at Manchester University in September 2007. Currently she is a member of the Work, Employment \& Society Editorial Board and a member of Warwick University's Industrial Relations Research Unit's (IRRU) Advisory Committee. 